Research article

\title{
IMMUNO-HISTOMORPHOMETRIC AND -FLUORESCENT CHARACTERISTICS OF GH CELLS AFTER TREATMENT WITH GENISTEIN OR DAIDZEIN IN AN ANIMAL MODEL OF ANDROPAUSE
}

\author{
AJDŽANOVIĆ Vladimir ${ }^{1}$, MEDIGOVIĆ Ivana ${ }^{1}$, ŽIVANOVIĆ Jasmina ${ }^{1}$, ŠOŠIĆ- \\ JURJEVIĆ Branka ${ }^{1}$, TRIFUNOVIĆ Svetlana ${ }^{1}$, TANIĆ Nasta ${ }^{2}$, MILOŠEVIĆ Verica ${ }^{1 *}$ \\ ${ }^{1}$ Department of Cytology, Institute for Biological Research "Siniša Stanković, University of Belgrade, \\ Belgrade, Serbia; ${ }^{2}$ Department of Radiobiology and Molecular Genetics, Institute of Nuclear Sciences \\ "Vinča", University of Belgrade, Belgrade, Serbia
}

(Received 25 December 2013; Accepted 27 January 2014)

\begin{abstract}
Somatopause, the complex aspect of andropause, is recognizable by reduced growth hormone - GH/insulin-like growth factor 1 axis function in the ageing male. Soy isoflavones (usually genistein and daidzein), which are known for their beneficial effects in the treatment of ageing symptoms, are active in the pituitary, as well. The immunohistomorphometric and -fluorescent characteristics of pituitary growth hormone secreting cells, in an animal model of andropause, were examined after a treatment with genistein or daidzein. Andropausal Wistar rats were divided into sham operated, orchidectomized and genistein or daidzein treated orchidectomized groups. Genistein or daidzein $(30 \mathrm{mg} / \mathrm{kg} /$ day) were administered subcutaneously for three weeks, while sham operated and orchidectomized groups received the vehicle alone. Growth hormone secreting cells were identified by the peroxidase-antiperoxidase immuno-histochemical, and immuno-fluorescent procedure. The main characteristic of growth hormone secreting cells in soy isoflavones treated groups is a weaker immuno-histochemical staining and immuno-fluorescent signal compared to sham operated and orchidectomized groups. The growth hormone secreting cell volume in orchidectomized + genistein or + daidzein groups is by $13.8 \%$ and $11.9 \%(\mathrm{p}<0.05)$ smaller respectively, in comparison with the orchidectomized group. In orchidectomized + genistein or +daidzein groups, the growth hormone secreting cells relative volume density is by $62.5 \%$ and $61.0 \%$ lower $(p<0.05)$ respectively than for the sham operated group, and decreased by $65.4 \%$ and $64.0 \%(\mathrm{p}<0.05)$ respectively, compared to the orchidectomized group. It can be concluded that chronic genistein or daidzein treatment, in an animal model of andropause, attenuates immunohistomorphometric and -fluorescent characteristics of growth hormone secreting cells.
\end{abstract}

Key words: andropause, GH cells, immuno-fluorescence, immuno-histochemistry, soy isoflavones

\section{INTRODUCTION}

The growth hormone (GH)/insulin-like growth factor (IGF1) axis is responsible for somatic development, while pituitary GH synthesis and secretion represent the integrated processes, controlled by hypothalamic, intrapituitary and peripheral signals, 
all of which converge on the GH cells [1] as the specific GH/IGF1 axis operative component. Andropause represents the culminating phase of ageing in males [2], i.e. the specific multi-symptomatic syndrome that is inter alia characterized by reduced GH/IGF1 axis function [3], which opens a specific thematic subfield - somatopause within the andropause. An age-related imbalance between the hypothalamic release of somatostatin and the growth hormone releasing-hormone (GHRH) causes a morphofunctional weakening of GH cells $[4,5]$ with a significant decrease in GH cells size and GH content per cell, as well as the GH pulse amplitude decline [6-8]. These changes appear to be followed by some adverse somatic consequences [9].

During the past several decades, soy isoflavones (usually genistein and daidzein), the compounds structurally and functionally similar to $17 \beta$-estradiol, have gained significant attention from the scientific community, primarily owing to their beneficial effects in the treatment of various ageing symptoms. On the other hand, data illustrating the effects of genistein or daidzein on the GH/IGF1 axis at different ages, and especially their effect on the pituitary GH cells histological characteristics, are limited. It was observed that genistein efficiently stimulates $\mathrm{GH}$ secretion in adult ewes, which is reflected in reduced $\mathrm{GH}$ deposition in the $\mathrm{GH}$ cells and elevated plasma $\mathrm{GH}$ levels [10]. Considering the negligible amount of estrogen receptors (ER) in GH cells [11], the authors proposed an indirect mechanism of genistein activity, via growth hormonereleasing hormone $(\mathrm{GHRH})$ [10]. The elaborated $\mathrm{GH}$ secretion promoting effect of genistein may encourage its potential therapeutic use in somatopause, while daidzein, inactive in the GHRH potentiation [12], still has a debatable potential role in this complex age-related condition.

Keeping in mind the silencing of the GH/IGF1 axis with ageing, the following negative morphofunctional transformation of $\mathrm{GH}$ cells (as the specific axis operative component), as well as a promising role of soy isoflavones in GH cells stimulation, the aim of this study was to investigate the effects of chronic subcutaneous treatment with genistein or daidzein on immuno-histomorphometric and fluorescent characteristics of GH cells in an animal model of andropause. Our ambition was to supplement the data 'pool' in the neglected aspect of GH cells histological characteristics, after the soy isoflavones application in advanced age. Orchidectomy was performed to eliminate testicular sex steroids from the hormonal millieu and their potential effects on the $\mathrm{GH}$ cells.

\section{MATERIALS AND METHODS}

\section{Animals and diets}

The experiments involved 16-month-old (andropausal) male Wistar rats. They were bred at the Institute for Biological Research "Siniša Stanković", Belgrade, Serbia, housed one per cage, exposed to a $12-12 \mathrm{~h}$ light-dark cycle and kept at $22 \pm 2^{\circ} \mathrm{C}$. Two weeks before the experiment, the rats were given a soy-free diet, prepared in cooperation with the Department of Animal Nutrition and Botany, Faculty of Veterinary Medicine, Belgrade, Serbia, and INSHRA PKB, Belgrade, Serbia, according to Picherit et al., (2000) [13] and our previous studies [14-16], with corn oil as the fat source. 
The diet contained per $100 \mathrm{~g}: 20.3 \mathrm{~g}$ casein; $65 \mathrm{~g}$ carbohydrate $(45 \mathrm{~g}$ cornstarch +20 $\mathrm{g}$ sucrose); $5.2 \mathrm{~g}$ corn oil; $3.7 \mathrm{~g}$ fiber (crystalline cellulose); $1.5 \mathrm{~g}$ vitamin/mineral mix (Ca-phosphate deficient); $1.8 \mathrm{~g}$ calcium-phosphate dibasic; $1 \mathrm{~g}$ calcium carbonate; $1.5 \mathrm{~g}$ DL-methionine. Casein and crystalline cellulose originated from Alfa Aesar, Johnson Matthey Gmbh \& Co. KG, Karlsruhe, Germany; carbohydrate, oil, vitamin/mineral mix, calcium carbonate and calcium phosphate from INSHRA PKB, Belgrade, Serbia; and DL-methionine from Sigma Chemical Company, St. Louis, MO, USA. Food and water were available ad libitum.

\section{Animal treatments}

At the age of 15 months experimental animals were bilaterally orchidectomized (Orx; $\mathrm{n}=24$ animals) or sham-operated ( $\mathrm{SO} ; \mathrm{n}=8$ animals) under Ketamine anesthesia $(15 \mathrm{mg} /$ kg b.w.; Richter Pharma, Wels, Austria). The recovery period lasted two weeks. The orchidectomized rats were then divided into three groups of eight animals $(n=8)$ each. The first group was subcutaneously treated with genistein (Nutraceutica, Monterenzio, Bologna, Italy; Orx+G), in a dose of $30 \mathrm{mg} / \mathrm{kg}$ b.w., every day except on Sundays, for 3 weeks. The second orchidectomized group received daidzein (Nutraceutica, Monterenzio, Bologna, Italy; Orx+D) at $30 \mathrm{mg} / \mathrm{kg}$ b.w., following the same regime. Genistein and daidzein were predissolved in a minimal volume of absolute ethanol $(0.17 \mathrm{ml})$ and mixed with sterile olive oil $(0.33 \mathrm{ml})$. The final volume injected was 0.5 $\mathrm{ml}$ per animal. The third orchidectomized group (Orx) and the SO group were given the same volume $(0.5 \mathrm{ml})$ of vehicle alone. Body mass in all groups was weighted before the surgery, before the treatment and after the treatment. All the animals $(n=32)$ were sacrificed by decapitation under ether anesthesia (ether ad narcosis Ph. Iug. III., Lek, Ljubljana, Slovenia) $24 \mathrm{~h}$ after the last injection. All experimental procedures were in compliance with the EEC Directive (86/609/EEC) on the protection of animals used for experimental and other scientific purposes, and were approved by the Ethical Committee for the Use of Laboratory Animals of the Institute for Biological Research "Siniša Stankovićc, University of Belgrade.

\section{Light microscopy and immuno-histochemistry}

The pituitary glands were excised, fixed in Bouins' solution for $48 \mathrm{~h}$ and embedded in paraplast. Serial $5 \mu \mathrm{m}$ thick tissue sections were deparafinised in xylol and rehydrated in a series of decreasing concentrations of ethanol. For light microscopy analysis, GH cells were immunolabelled using the peroxidase-antiperoxidase complex (PAP) method of Sternberger et al. (1970) [17]. The endogenous peroxidase activity was blocked by incubation in $9 \mathrm{mmol}(0.3 \%)$ hydrogen peroxide solution in methanol, for $15 \mathrm{~min}$ at $24^{\circ} \mathrm{C}$. Before the application of the specific primary antisera, nonspecific background staining was prevented by incubation of the sections with nonimmune, i.e. normal porcine serum, diluted (1:10) with phosphate buffered saline (PBS) pH 7.4, for 60 min at $24^{\circ} \mathrm{C}$. Sections were then overlaid with the appropriate dilutions of the specific primary antibodies (hGHantisera, Dako A/S, Glostrup, Denmark; diluted 1:200 in PBS) for $24 \mathrm{~h}$ at $24^{\circ} \mathrm{C}$. This antibody strongly cross-reacts with rat GH [18]. After washing in PBS for 
$5 \mathrm{~min}$, sections were incubated for $60 \mathrm{~min}$ at $24^{\circ} \mathrm{C}$ with a secondary antibody, swine antirabbit IgG (DAKO, Glostrup, Denmark; diluted 1:100 in PBS), rinsed again in PBS for 5 min and then incubated with rabbit PAP complex (DAKO A/S, Glostrup, Denmark; diluted 1:100 in PBS), for $45 \mathrm{~min}$ at $24^{\circ} \mathrm{C}$. Binding sites were visualized using $0.05 \%$ diaminobenzidine (DAB, Serva, Heidelberg, Germany) and $0.03 \%$ hydrogen peroxide in 0.2 M TRIS-HCl buffer, $\mathrm{pH}$ 7.4. The sections were counterstained with hematoxylin and mounted in Canada balsam (Molar Chemicals KFT, Budapest, Hungary). For the negative control sections, the primary antibody was omitted and replaced by PBS.

\section{Immuno-fluorescent studies}

GH cells were also localized immuno-fluorescently. In brief, the pituitary sections were deparafinised, rehydrated, washed in PBS and pretreated with blocking normal donkey serum (Dako, Glostrup, Denmark), diluted in PBS (1:10). After blocking, sections were incubated overnight at $24^{\circ} \mathrm{C}$ with the specific primary antibodies (hGHantisera, Dako A/S, Glostrup, Denmark; diluted 1:200 in PBS). After rinsing in PBS, the sections were covered, for $2 \mathrm{~h}$ at $24^{\circ} \mathrm{C}$, with secondary antibody Alexa Fluor 488 donkey anti-rabbit IgG (Molecular Probes, Inc., USA; 1:200). Finally, sections were rinsed five times in PBS and mounted using Mowiol 4-88 (Sigma-Aldrich, Co., USA). Carl Zeiss AxioVision microscope (Zeiss, Germany) was used for the section analysis. The negative controls were obtained by replacement of the primary antibody with a PBS.

Analysis of fluorescent images was performed using the Image J 1.47 (public domain Java image processing program by National Institutes of Health (NIH)). The relative intensity of fluorescence (RIF, \%) was measured on 100-150 cells per animal in which the nucleus was apparent.

\section{Morphometry}

Morphometrical measurements were performed as described previously [14, 15]. Namely, two pituitary sections ( $5 \mu \mathrm{m}$ thick) from the superior, three from the middle and two from the inferior part (seven horizontal sections, $20 \mu \mathrm{m}$ apart in total) of the rat pituitary glands were analysed. The point counting method was used at an overall magnification of $x 1000$ [19]. The $\mathrm{M}_{42}$ multipurpose test grid, inserted into the ocular of a Zeiss light microscope (Jena, Germany), was randomly positioned on the pituitary section at the beginning of counting. Counting was carried out on the following 50 test fields per section. Average values were calculated per pituitary i.e. per animal $(7$ sections, 350 test fields) and five pituitaries were analyzed per group. Cell volume $\left(\mathrm{Vc}, \mu \mathrm{m}^{3}\right)$, volume of the nuclei $\left(\mathrm{Vn}, \mu \mathrm{m}^{3}\right)$ and volume density (percentage of immunoreactive cells in $\mu \mathrm{m}^{3}$; Vvc, \%) were determined for $\mathrm{GH}$-immunoreactive cells.

The following parameters were counted:

Pn - number of points hitting on nuclei of immuno-histochemically labeled cells inside the test field

Ptc - number of points hitting on cytoplasm of immuno-histochemically labeled cells inside the test field

$\mathrm{Nn}$ - number of immuno-histochemically labeled cell nuclei inside the test field. 
The formula for calculating the nuclei volume was:

$\mathrm{Vn}=\mathrm{V}_{\mathrm{Vn}} / \mathrm{N}_{\mathrm{V}}$

and that for the cell volume calculation was:

$\mathrm{Vc}=1 / \mathrm{N}_{\mathrm{V}}$, where

$\mathrm{V}_{\mathrm{Vn}}$ is - the volume density of GH cell nuclei and $\mathrm{N}_{\mathrm{V}}$ - the numerical density of $\mathrm{GH}$ cells. Nuclei volume density $\left(\mathrm{V}_{\mathrm{Vn}}\right)$ provides information about nuclei attendance in the estimated cells and is calculated as follows:

$\mathrm{V}_{\mathrm{Vn}}=\Sigma \mathrm{Pn} / \Sigma \mathrm{Ptc}$

Since rat $\mathrm{GH}$ cells are mononuclear, $\mathrm{N}_{\mathrm{V}}$ corresponds to the number of cells per cubic millimetre, according to the formula:

$\mathrm{N}_{\mathrm{V}}=(\mathrm{k} / \beta)\left(\mathrm{N}_{\mathrm{A}}^{3 / 2} / \mathrm{V}_{\mathrm{Vn}}^{1 / 2}\right)$

On the basis of earlier karyometric studies [20], the shape coefficient $\beta$ for pituitary cells was estimated to be 1.32 , where $\mathrm{k}$ is a factor related to cell distribution according to their size (in the case of GH cells its value is 1) and $\mathrm{N}_{\mathrm{A}}$ is the number of cells in the plane of the pituitary tissue section. $\mathrm{N}_{\mathrm{A}}$ is calculated as follows:

$\mathrm{N}_{\mathrm{A}}=\Sigma \mathrm{Nn} / \Sigma \mathrm{Ptc} \cdot \mathrm{a}$,

where a represents the rhombic area belonging to every point of the test system and is calculated using the formula:

$\mathrm{a}=\mathrm{d}^{2} 3^{1 / 2} / 2$,

where $\mathrm{d}$ is the test line length in the test system employed.

Volume density $\left(\mathrm{V}_{\mathrm{vC}}\right)$ is calculated as the ratio of the sum of Pn and Ptc $(\mathrm{Pn}+\mathrm{Ptc})$ and the total number of points in the test system. Since the test system with 42 points was used and parameters were calculated using 50 test fields, the definite formula was:

$\mathrm{V}_{\mathrm{vC}}=(\operatorname{Pn}+\mathrm{Ptc}) / 50 \cdot 42$

\section{Statistical analysis}

STATISTICA ${ }^{\circledR}$ version 7.0 (StatSoft, Inc.) was used for the statistical analysis. Morphometric and RIF data obtained for the experimental groups were subjected to one-way analyses of variance (ANOVA). Duncan's multiple range tests were used for post hoc comparisons between groups. A confidence level of $\mathrm{p}<0.05$ was considered statistically significant. The data are presented as means \pm SD.

\section{RESULTS}

\section{Body mass and pituitary weights}

Data for body mass, absolute and relative pituitary weights are summarized in Table 1. Only in the Orx group the body mass after treatment was significantly $(\mathrm{p}<0.05)$ decreased (by 9.8\%), in comparison with the SO group. Genistein or daidzein treatment, after orchidectomy, returned the body mass to the values similar to that of SO rats. Absolute pituitary weight was significantly $(\mathrm{p}<0.05)$ increased in Orx $+\mathrm{D}$ group by $8.4 \%$, compared to the Orx group. The relative pituitary weights were significantly $(p<0.05)$ increased in Orx, Orx $+\mathrm{G}$ and Orx $+\mathrm{D}$ groups by $13.6 \%, 40.9 \%$ and $31.8 \%$ respectively, in comparison with the SO group. The relative pituitary weight increased by $24.0 \%$ $(p<0.05)$ for the Orx $+G$ and by $15.0 \%$ for the Orx $+D$, compared to the Orx group. 
Table 1. Body mass, absolute and relative pituitary weight in sham-operated (SO), orchidectomized (Orx), genistein $(\mathrm{Orx}+\mathrm{G})$ and daidzein $(\mathrm{Orx}+\mathrm{D})$ treated orchidectomized andropausal rats.

\begin{tabular}{lcccc}
\hline & SO & Orx & Orx+G & Orx+D \\
\hline $\begin{array}{l}\text { Body mass before } \\
\text { surgery (g) }\end{array}$ & & \multicolumn{2}{c}{$680.0 \pm 30.0$} & \\
$\begin{array}{l}\text { Body mass before } \\
\text { treatment (g) }\end{array}$ & $654.0 \pm 8.0$ & $639.0 \pm 63.0$ & $639.0 \pm 63.0$ & $639.0 \pm 63.0$ \\
$\begin{array}{l}\text { Body mass after } \\
\text { treatment (g) }\end{array}$ & $650.0 \pm 29.0$ & $586.0 \pm 35.0^{\mathrm{a}}$ & $635.0 \pm 57.0^{\mathrm{b}}$ & $620.0 \pm 46.0^{\mathrm{b}}$ \\
$\begin{array}{l}\text { Absolute pituitary } \\
\text { weight (mg) }\end{array}$ & $17.0 \pm 1.7$ & $16.6 \pm 1.4$ & $19.6 \pm 1.0^{\mathrm{b}}$ & $18.0 \pm 1.4^{\mathrm{b}}$ \\
$\begin{array}{l}\text { Relative pituitary } \\
\text { weight }(\mathrm{mg} / \%)\end{array}$ & $2.2 \pm 0.1$ & $2.5 \pm 0.2^{\mathrm{a}}$ & $3.1 \pm 0.2^{\mathrm{a}, \mathrm{b}}$ & $2.9 \pm 0.2^{\mathrm{a}, \mathrm{b}}$ \\
\hline
\end{tabular}

Means \pm SD, $n=5 /$ group; ${ }^{\mathrm{a}} \mathrm{p}<0.05 v$ s. sham-operated $(\mathrm{SO})$ rats; ${ }^{\mathrm{b}} \mathrm{p}<0.05 v$ s. orchidectomized (Orx) rats

\section{Immuno-histochemical findings}

Immunopositive GH cells in SO and Orx rat pituitaries are mainly uniformly distributed, bilaterally and rostrocaudally, in the pars distalis, while being completely absent in the pituitary pars intermedia. They can be observed as an individual or as a group, especially along the sinusoidal capillaries (Fig. 1A, B). SO and Orx rat pituitary GH cells appear to be massive, ovoid to pyramidal in shape, with a spherical, centrally located nucleus. The immunospecific signal, reflecting the cells' GH content, is rather dark and widely distributed throughout the cytoplasm (Fig. 1A, B). In Orx $+\mathrm{G}$ and Orx $+\mathrm{D}$ rat pituitaries, a small number of immunopositive $\mathrm{GH}$ cells can be observed; they appear as an individual or in the form of small groups, along the sinusoidal capillaries (Fig. 1C, D). The main characteristic of GH cells in soy isoflavones treated groups of rats is enlightened cytoplasm (a weaker intensity of immunospecific staining compared to the control groups), while the pituitary capillaries, towards which GH cells gravitate, are dilated (Fig. 1C, D).

\section{Immuno-fluorescent findings}

Complementary insight into the immuno-fluorescent appearance of GH cells confirmed a weaker signal after the soy isoflavone treatments, compared to the control groups (Fig. 2A-D). Quantification of the signal revealed that in Orx $+\mathrm{G}$ rats RIF is decreased by $41.8 \%$ and $44.8 \%(\mathrm{p}<0.05)$ in comparison with the SO and Orx group, respectively (Fig. 2E). Daidzein treatment of orchidectomized andropausal rats $(\mathrm{Orx}+\mathrm{D})$ also causes the decrease of RIF for $47.3 \%$ and $50.0 \%(\mathrm{p}<0.05)$ compared to the SO and Orx group, respectively.

\section{Morphometric results}

Morphometric analyses showed that $\mathrm{GH}$ cells in $\mathrm{SO}$, Orx, Orx $+\mathrm{G}$ and Orx $+\mathrm{D}$ groups of rats have a mean cell volume (Vc) of $591 \mu \mathrm{m}^{3}, 559 \mu \mathrm{m}^{3}, 482 \mu \mathrm{m}^{3}$ and $492 \mu \mathrm{m}^{3}$, 

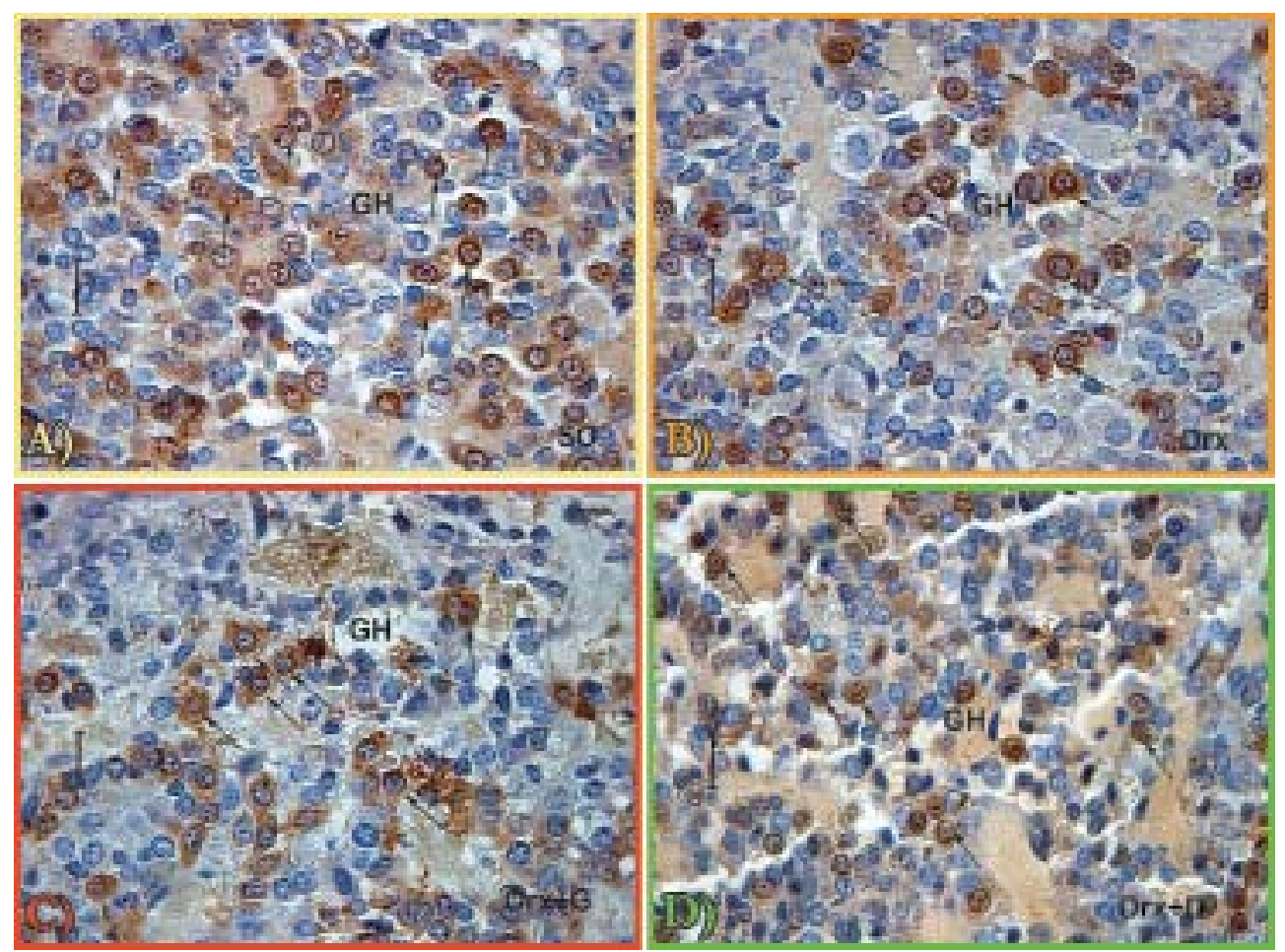

Figure 1. Immunopositive GH cells in pars distalis of the pituitary gland from: A) sham-operated $(\mathrm{SO}), \mathrm{B})$ orchidectomized (Orx), C) genistein $(\mathrm{Orx}+\mathrm{G})$ and $\mathrm{D})$ daidzein $(\mathrm{Orx}+\mathrm{D})$ treated orchidectomized andropausal rats (magnification $63 \mathrm{x}$, bar $=16 \mu \mathrm{m}$ )

respectively (Fig. 3A). In comparison with SO and Orx groups, the $\mathrm{GH}$ cell volume in Orx $+G$ group is $18.4 \%$ and $13.8 \%(\mathrm{p}<0.05)$ smaller, respectively (Fig. 3A). The mentioned parameter in Orx $+\mathrm{D}$ group of rats is also significantly $(\mathrm{p}<0.05)$ decreased compared to SO and Orx groups, by $16.8 \%$ and $11.9 \%$ respectively (Fig. 3A). After orchidectomy and orchidectomy followed by soy isoflavones treatment there are no significant $(p>0.05)$ changes in the nuclear volumes of GH cells, in comparison with the SO group (Fig. 3B). The GH cells relative volume density data (Vvc; \%) in SO, Orx, Orx $+\mathrm{G}$ and Orx $+\mathrm{D}$ groups are shown in Fig. 3C (36.0\%, 39.0\%, 13.5\% and 14.2\% respectively). Namely, in Orx $+\mathrm{G}$ and $\mathrm{Orx}+\mathrm{D}$, the relative volume densities are by $62.5 \%$ and $61.0 \%$ lower $(\mathrm{p}<0.05)$ respectively, than for the SO controls (Fig. $3 \mathrm{C})$. The same parameter in Orx $+G$ and Orx $+D$ is significantly $(p<0.05)$ decreased by $65.4 \%$ and $64.0 \%$ respectively, compared to Orx group (Fig. 3C).

\section{DISCUSSION}

Considering the promising data regarding the soy isoflavone effects in ageing, somewhat of their GH/IGF1 axis stimulation, as well as the limited information about the GH cells appearance in this context, our intention was to determine the immunohistomorphometric and -fluorescent characteristics of GH cells in andropausal rats, after chronic genistein or daidzein treatment. 

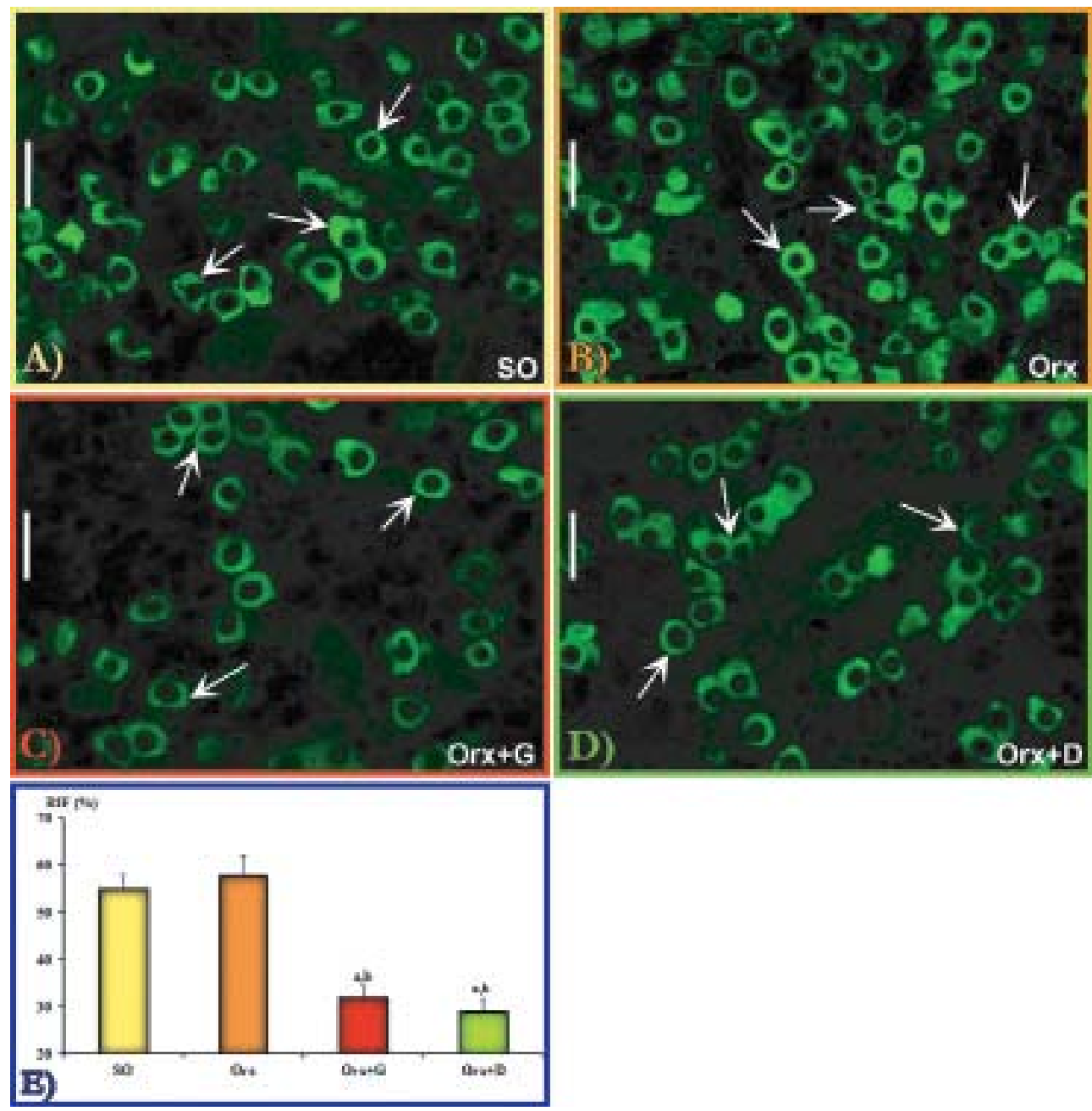

Figure 2. Immuno-fluorescent appearance of GH cells in pars distalis of the pituitary gland from: A) sham-operated (SO), B) orchidectomized (Orx), C) genistein (Orx $+\mathrm{G})$ and D) daidzein $($ Orx + D) treated orchidectomized andropausal rats $(\mathrm{bar}=20 \mu \mathrm{m})$; E) Relative intensity of fluorescence (RIF, \%) measured in GH cells from SO, Orx, Orx $+\mathrm{G}$ and Orx $+\mathrm{D}$ groups. All values are the means $\pm \mathrm{SD}, \mathrm{n}=5$ animals per group; ${ }^{\mathrm{a}} \mathrm{p}<0.05 v$ s. $\mathrm{SO},{ }^{\mathrm{b}} \mathrm{p}<0.05 v s$. Orx

In line with our previous findings [14, 15], genistein or daidzein application to orchidectomized andropausal rats has some recovering body mass effect, i.e. it brings body mass values close to that of SO rats. We have already demonstrated the pronounced daidzein effects on the prevention of bone loss and calcium excretion in the same animal model [21], while Penza et al. [22] observed that nutritional doses of genistein are adipogenic in male mice, all of which can cause the positive body weight outcome in our experiment. It should be mentioned that some studies suggest the absence of soy isoflavones effect on body mass [23], so the cautiousness in concluding is desirable. On the other hand, given the age of animals in our study and their long-ended growth, it is quite reasonable to minimize the importance of some potentional genistein or daidzein 

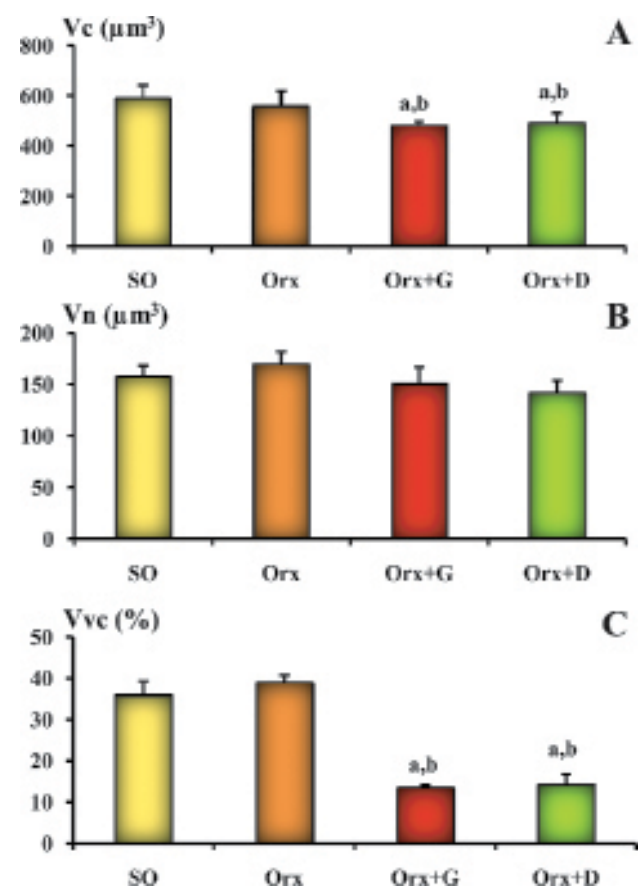

Figure 3. Cellular $\left(\mathrm{Vc}, \mu \mathrm{m}^{3} ; \mathrm{A}\right)$ and nuclear volume $\left(\mathrm{Vn}, \mu \mathrm{m}^{3} ; \mathrm{B}\right)$, and relative volume density ( $\mathrm{Vvc}, \%$; $\mathrm{C}$ ) of $\mathrm{GH}$ cells in: sham-operated $(\mathrm{SO})$, orchidectomized (Orx), genistein $(\mathrm{Orx}+\mathrm{G})$ and daidzein $(\mathrm{Orx}+\mathrm{D})$ treated orchidectomized andropausal rats. All values are given as the means \pm SD, $\mathrm{n}=5$ animals per group; ${ }^{\mathrm{a}} \mathrm{p}<0.05$ vs. SO, ${ }^{\mathrm{b}} \mathrm{p}<0.05$ vs. Orx

effect on the body mass via GH/IGF1 axis. Also, genistein or daidzein treatment increases absolute and relative pituitary weight in orchidectomized andropausal rats, which is explicable by their presumable estrogenic effect on the pituitary prolactin cells. A weaker intensity of immuno-histochemical staining and immuno-fluorescent signal of GH cells, followed by their decreased volume and volume density, compared to both SO and Orx groups, is observed after genistein or daidzein application in our experiment. Genistein, operating as a tyrosine-kinase inhibitor, promotes GHRHstimulated cAMP accumulation in GH cells, which potentiates their hormonal content secretion [12]. This mechanism may satisfactorily clarify the observed appearance of the cytoplasm of GH cells after genistein treatment in our study. Furthermore, genistein treatment lowered the density of the immunoreactive material in GH cells of ewes, which indicates decreased hormone storage [10]. Daidzein, although a weak tyrosinekinase inhibitor [24], fashions in a similar manner as genistein in orchidectomized andropausal rats, which opens the space for some other possible mechanisms of soy isoflavone actions pertinent to GH cells. Literature data indicate the possible alterations in somatostatin receptors (SSTRs) expression after genistein application in vitro, as a matter of fact the SSTR1 downregulation, as well as the SSTR2 and SSTR5 upregulation [25]. Considering that an alternative SSTR expression in pituitary GH secreting tumors causes the insensitivity to somatostatin [26], it seems logical that some soy isoflavone modified SSTR expression in GH cells may have a related outcome responsible for 
shaping their appearance.

Based on the above elaborated issues, it can be concluded that chronic genistein or daidzein treatment, in an animal model of andropause, attenuates immunohistomorphometric and -fluorescent characteristics of GH cells.

\section{ACKNOWLEDGEMENTS}

This work was supported by the Ministry of Education, Science and Technological Development of the Republic of Serbia, grant number 173009. The authors are especially grateful to Zdenko Tojčić (»Galen Focus«, Belgrade, Serbia) and Goran Granić (»Promedia«, Zrenjanin, Serbia) for their technical support.

\section{REFERENCES}

1. Melmed S: Idiopathic adult growth hormone deficiency. J Clin Endocrinol Metab 2013, 98:2187-2197.

2. Morales A: Andropause (or symptomatic late-onset hypogonadism): facts, fiction and controversies. Aging Male 2004, 7:297-303.

3. Thompson CA, Shanafelt TD, Loprinzi CL: Andropause: symptom management for prostate cancer patients treated with hormonal ablation. Oncologist 2003, 8:474-487.

4. Epelbaum J: Neuroendocrinology and aging. J Neuroendocrinol 2008, 20:808-811.

5. Milosevic V, Trifunovic S, Sosic-Jurjevic B, Bujsic N, Sekulic M: Estradiol and calcium affect the growth hormone producing cells in female middle-aged rats. Acta Vet-Beograd 2005, 55:111-120.

6. Russell-Aulet M, Dimaraki EV, Jaffe CA, DeMott-Friberg R, Barkan AL: Aging-related growth hormone $(\mathrm{GH})$ decrease is a selective hypothalamic $\mathrm{GH}$-releasing hormone pulse amplitude mediated phenomenon. J Gerontol A Biol Sci Med Sci 2001, 56:M124-129.

7. Kuwahara S, Sari DK, Tsukamoto Y, Tanaka S, Sasaki F: Age-related changes in growth hormone $(\mathrm{GH})$ cells in the pituitary gland of male mice are mediated by GH-releasing hormone but not by somatostatin in the hypothalamus. Brain Res 2004, 998:164-173.

8. Takahashi S: Heterogenity and development of somatotrophs and mammotrophs in the rat. Zoolog Sci 1992, 9:901-924.

9. Ceda GP, Dall'Aglio E, Morganti S, Denti L, Maggio M, Lauretani F, Andrea A, Ceresini G, Cattabiani C, Valenti G: Update on new therapeutic options for the somatopause. Acta Biomed 2010, 81 Suppl 1:67-72.

10. Misztal T, Wankowska M, Gorski K, Romanowicz K: Central estrogen-like effect of genistein on growth hormone secretion in the ewe. Acta Neurobiol Exp (Wars) 2007, 67:411-419.

11. Scanlan N, Skinner DC: Estradiol modulation of growth hormone secretion in the ewe: no growth hormone-releasing hormone neurons and few somatotropes express estradiol receptor alpha. Biol Reprod 2002, 66:1267-1273.

12. Ogiwara T, Chik CL, Ho AK: Tyrosine kinase inhibitors enhance GHRH-stimulated cAMP accumulation and GH release in rat anterior pituitary cells. J Endocrinol 1997, 152:193-199. 
13. Picherit C, Coxam V, Bennetau-Pelissero C, Kati-Coulibaly S, Davicco MJ, Lebecque P, Barlet JP: Daidzein is more efficient than genistein in preventing ovariectomy-induced bone loss in rats. J Nutr 2000, 130:1675-1681.

14. Ajdzanovic VZ, Sosic-Jurjevic BT, Filipovic BR, Trifunovic SL, Milosevic V: Daidzein effects on ACTH cells: immunohistomorphometric and hormonal study in an animal model of the andropause. Histol Histopathol 2011, 26:1257-1264.

15. Ajdzanovic VZ, Sosic-Jurjevic BT, Filipovic BR, Trifunovic SL, Brkic DD, Sekulic MI, Milosevic V: Genistein affects the morphology of pituitary ACTH cells and decreases circulating levels of ACTH and corticosterone in middle-aged male rats. Biol Res 2009, 42:13-23.

16. Pantelic J, Filipovic B, Sosic-Jurjevic B, Ajdzanovic V, Trifunovic S, Medigovic I, Milosevic $\mathrm{V}$ : Vitex agnus-castus essential oil affects thyroid $\mathrm{C}$ cells and bone metabolism in middleaged male rats. Acta Vet-Beograd 2013, 63:23-35.

17. Sternberger LA, Hardy PH, Jr., Cuculis JJ, Meyer HG: The unlabeled antibody enzyme method of immunohistochemistry: preparation and properties of soluble antigen-antibody complex (horseradish peroxidase-antihorseradish peroxidase) and its use in identification of spirochetes. J Histochem Cytochem 1970, 18:315-333.

18. Milosevic V, Brkic B, Velkovski S, Starcevic V: Somatostatin induced changes of the ACTH and STH cells in the hypophysis of the male rats. Jugoslav Med Biohem 1994, 13:102-106.

19. Weibel ER: 1. Practical Methods for Biological Morphometry. In: Stereological Methods. London, UK: Academic Press; 1979, 1-415.

20. Poole MC, Kornegay $3^{\text {rd }}$ WD: Cellular distribution within the rat adenohypophysis: a morphometric study. Anat Rec 1982, 204:45-53.

21. Filipovic B, Sosic-Jurjevic B, Ajdzanovic V, Brkic D, Manojlovic-Stojanoski M, Milosevic V, Sekulic M: Daidzein administration positively affects thyroid C cells and bone structure in orchidectomized middle-aged rats. Osteoporos Int 2010, 21:1609-1616.

22. Penza M, Montani C, Romani A, Vignolini P, Pampaloni B, Tanini A, Brandi ML, AlonsoMagdalena P, Nadal A, Ottobrini L et al: Genistein affects adipose tissue deposition in a dose-dependent and gender-specific manner. Endocrinology 2006, 147:5740-5751.

23. Faqi AS, Johnson WD, Morrissey RL, McCormick DL: Reproductive toxicity assessment of chronic dietary exposure to soy isoflavones in male rats. Reprod Toxicol 2004, 18:605-611.

24. Yokoshiki H, Sumii K, Sperelakis N: Inhibition of L-type calcium current in rat ventricular cells by the tyrosine kinase inhibitor, genistein and its inactive analog, daidzein. J Mol Cell Cardiol 1996, 28:807-814.

25. Zhong W, Atkin SL: Modulation of somatostatin receptors expression by genistein in human umbilical vein endothelial cells. Endocrine Abstracts 2005, 9:P38.

26. Barbieri F, Bajetto A, Pattarozzi A, Gatti M, Wurth R, Thellung S, Corsaro A, Villa V, Nizzari M, Florio T: Peptide receptor targeting in cancer: the somatostatin paradigm. Int J Pept 2013, 2013:926295. 


\title{
IMUNO-HISTOMORFOMETRIJSKE I -FLUORESCENTNE KARAKTERISTIKE GH ĆELIJA NAKON TRETMANA GENISTEINOM ILI DAIDZEINOM U ANIMALNOM MODELU ANDROPAUZE
}

\author{
AJDŽANOVIĆ Vladimir, MEDIGOVIĆ Ivana, ŽIVANOVIĆ Jasmina, ŠOŠIĆ- \\ JURJEVIĆ Branka, TRIFUNOVIĆ Svetlana, TANIĆ Nasta, MILOŠEVIĆ Verica
}

Somatopauza, kao kompleksan aspekt andropauze, je prepoznatljiva po sniženom nivou funkcije somatotropne - GH ose kod starih mužjaka. Izoflavoni soje (najčešće genistein i daidzein), imaju blagotvorne efekte pri tretmanu simptoma starenja, a ispoljavaju svoje dejstvo i na nivou hipofize. Imuno-histomorfometrijske i - fluorescentne karakteristike hipofiznih somatotropnih ćelija su ispitivane nakon tretmana genisteinom ili daidzeinom, u animalnom modelu andropauze. Pacovi Wistar soja u andropauzi su podeljeni u nekoliko grupa: prividno operisanu, orhidektomisanu i genisteinom odnosno daidzeinom tretiranu orhidektomisanu grupu. Rastvoreni genistein, odnosno daidzein (30 mg/kg/dan) su potkožno davani tokom tri nedelje, dok su prividno operisana i orhidektomisana grupa dobijale samo rastvarač tokom istog perioda. Somatotropne ćelije su identifikovane peroksidaza-antiperoksidaza imuno-histohemijskom, i imunofluorescentnom metodom. Osnovna karakteristika somatotropnih ćelija u grupama tretiranim izoflavonima soje je slabije imuno-histohemijsko bojenje i slabiji imunofluorescentni signal u poređenju sa prividno operisanom i orhidektomisanom grupom. Volumen somatotropnih ćelija u orhidektomisanoj i genisteinom, odnosno daidzeinom tretiranoj grupi je za 13,8\%, odnosno 11,9\% ( $\mathrm{p}<0,05)$ smanjen u poređenju sa orhidektomisanom grupom. U orhidektomisanoj i genisteinom, odnosno daidzeinom tretiranoj grupi volumenska gustina somatotropnih ćelija je za 62,5\%, odnosno $61,0 \%$ niža $(p<0,05)$ nego kod prividno operisane grupe, te za $65,4 \%$, odnosno $64,0 \%(p<0,05)$ niža u poređenju sa orhidektomisanom grupom. Može se zaključiti da hronični tretman genisteinom ili daidzeinom, $u$ animalnom modelu andropauze, ima negativan efekat na imuno-histomorfometrijske i - fluorescentne karakteristike somatotropnih ćelija. 